\title{
Population genetics analysis of Podocnemis sextuberculata (Testudines, Podocnemidae): lack of population structure in the central Amazon Basin
}

\author{
T.J. Silva ${ }^{1,2}$, L.A.S. Monjeló ${ }^{1}$, M.N.S. Viana ${ }^{1}$, J.C. Pezzuti ${ }^{3}$, \\ P.C.M. Andrade ${ }^{4}$, R.C. Vogt $^{5}$ and I.P. Farias ${ }^{1}$ \\ 'Laboratório de Evolução e Genética Animal, Departamento de Biologia, \\ Universidade Federal do Amazonas, Manaus, AM, Brasil \\ ${ }^{2}$ Universidade Federal de Alagoas, Campus Arapiraca-Pólo Penedo, \\ Arapiraca, AL, Brasil \\ ${ }^{3}$ Universidade Federal do Pará, Belém, PA, Brasil \\ ${ }^{4}$ Faculdade de Ciências Agrárias, Universidade Federal do Amazonas, \\ Manaus, AM, Brasil \\ ${ }^{5}$ Coordenação de Pesquisa em Biologia de Água Doce, \\ Instituto Nacional de Pesquisas da Amazônia, Manaus, AM, Brasil \\ Corresponding author: T.J. Silva \\ E-mail: themisilva@yahoo.com.br
}

Genet. Mol. Res. 10 (3): 1393-1402 (2011)

Received November 19, 2010

Accepted February 24, 2011

Published July 12, 2011

DOI 10.4238/vol10-3gmr1163

\begin{abstract}
The chelonians are, in general, important for the economy of the traditional populations of the Amazon region, especially as a source of animal protein. Furthermore, sub-products, such as eggs and fat, are utilized in the manufacture of cosmetics, and the plastron and carapace are used in the manufacture of adornments. The freshwater turtle species Podocnemis sextuberculata, locally known as "iaçá" or "pitiú", is widely distributed in the Amazon Basin in Brazil and
\end{abstract}


also in Colombia and Peru. This species is on the International Union for Conservation of Nature Red List in the category of vulnerable species. We examined the genetic variability and population structure of three populations represented by 64 individuals sampled from Reserva Federal de Abufari, Tapauá, Amazonas State; Reserva de Desenvolvimento Sustentável Mamirauá, Tefé, Amazonas State, and Terra Santa, Pará State. All of these are over $1000 \mathrm{~km}$ from each other. A partial 415-bp sequence of the mitochondrial gene ND1 was utilized as a molecular marker. Seven haplotypes were observed; the most common haplotype was shared by all the areas sampled, while the rarest haplotypes were represented by a single individual and were thus restricted to a single locality. The sharing of the most common haplotype, the high number of migrants $(\mathrm{Nm})$ and the AMOVA results indicate a lack of genetic structure among the sampling localities. The levels of genetic variability observed were homogeneous among the sampling localities. These results $\left(\theta_{S T}\right.$ and $\left.\mathrm{Nm}\right)$ are compatible with what is known about the ecology of this species, which has a great migratory capacity.

Key words: Chelonians; Iaçá; Amazon basin; Mitochondrial DNA; Podocnemis sextuberculata

\section{INTRODUCTION}

In Brazil, the genus Podocnemis is represented by four species, one of which is Podocnemis sextuberculata, known commonly as "iaçá", "pitiú" or "cambéua". This species can be found in the white-water rivers such as the Solimões, Amazonas and Branco, as well as in the lower section of clear- and black-water rivers such as the Trombetas, Tapajós, Xingu, and Negro. P. sextuberculata is found not only in Brazil but also in many rivers in Colombia and Peru. The female possesses yellow patches with two barbels below the mouth. In young individuals, the plastron has six projecting gray or brown points (tubercles), hence the name $P$. sextuberculata. The eggs have soft shells, and the average clutch is 20-25 (IBAMA, 1989). Podocnemis sextuberculata is economically important for Amazonian riverbank inhabitants, where their meat and eggs are often appreciated (SEBRAE, 1995). Furthermore, their sub-products such as fat are utilized in the manufacture of cosmetics, and the plastron and carapace are used in the manufacture of adornments.

Podocnemis sextuberculata is on the IUCN Red List in the category of vulnerable species (IUCN, 2009). The basic criterion for such classification is a decrease in census sizes of natural populations. However, according to Fachín-Terán et al. (2003), there are no quantitative biological data for this species that support such classification in any of the countries where it occurs. The lack of biological and ecological data for this species hinders the determination of its current status, and, in particular, the introduction of management and conservation practices.

The management of many threatened species is based on knowledge of their population dynamics, as specific demographic information is lacking, mainly with regard to 
the chelonians, which are organisms that show longevity (Finch, 1990; Lutz et al., 2003). Population genetic data are one of the most important baseline components of any conservation and management plan (Frankham et al., 2002). Chelonian management, that is their conservation and breeding in captivity, depends on knowledge of the patterns of variability and genetic structure of the populations in different regions, combined with data on their ecology, physiology, nutrition, and reproduction.

Considering the economic importance, the history of the exploitation of P. sextuberculata in the Amazon region (Fachín-Terán et al., 2000), and the total lack of data on its population genetics, the central objective of this study was to characterize the variability and the genetic structure of natural populations of this species in three Amazon Basin locations, utilizing the ND1 gene of mitochondrial DNA (mtDNA).

Genes of mtDNA have quite often been utilized in genetic studies of freshwater turtles, sea turtles, and tortoises. Population genetics as well as the genetics of the reproductive system have been studied in the Amazon River turtle P. expansa (Sites Jr. et al., 1999; Pearse et al., 2006a,b). More recently, P. lewyana, a species endemic to northern Colombia, has been genetically characterized using the cytochrome $b$ gene (Vargas-Ramírez et al., 2007), and the mating system of $P$. unifilis has been studied with microsatellite DNA markers (Fantin et al., 2008). In the study of P. expansa from the Amazon Basin, Pearse et al. (2006a) utilized mitochondrial and microsatellite markers in individuals drawn from various hydrographic basins. The authors found a lack of population structure in tributaries of the same hydrographic basin, but genetic differences among basins. Ecological data have suggested that $P$. sextuberculata shows a high capacity for dispersion (Fachín-Terán et al., 2006), which may lead to a lack of population differentiation within the Amazon Basin, similar to that observed with $P$. expansa. In this study, we tested the null hypothesis of panmixia of the populations of this species among Amazon Basin locations that are separated by distances over $1000 \mathrm{~km}$, using the mtDNA gene ND1.

\section{MATERIAL AND METHODS}

\section{Sample collection, DNA extraction and polymerase chain reaction (PCR)}

The samples were collected at Reserva Biológica Federal do Abufari, Tapauá Municipality (Middle Purus River), Amazonas State; at Reserva de Desenvolvimento Sustentável Mamirauá (RDS Mamirauá), Tefé Municipality (between Solimões and Japurá Rivers), Amazonas State, and at Terra Santa (Lower Amazon River), Pará State in a chelonian management area of the "Pé-de-pincha" project (Figure 1). A total de 64 individuals were collected, 29 from the Reserva Biológica Federal do Abufari, 11 from RDS Mamirauá and 24 from Terra Santa. Total genomic DNA was extracted from $0.5 \mathrm{~mL}$ blood per individual following the phenol/chloroform protocol (Sambrook et al., 1989) with few modifications.

The partial mitochondrial ND1 gene was amplified by PCR using the primers 16SF.2 and MetR.1 (Hrbek et al., 2002). PCR was carried out in a $25-\mu \mathrm{L}$ total volume and consisted of $1 \mu \mathrm{L}$ DNA (approximately $100 \mathrm{ng}$ DNA), $2 \mu \mathrm{L} 2 \mu \mathrm{M}$ of each primer, $2.5 \mu \mathrm{L} 10 \mathrm{X}$ buffer (200 mM Tris-KCl, $\mathrm{pH} 8.5), 3 \mu \mathrm{L} 25 \mathrm{mM} \mathrm{MgCl}, 2.5 \mu \mathrm{L} 10 \mathrm{mM}$ dNTP, $0.2 \mu \mathrm{L} 5 \mathrm{U} / \mu \mathrm{L}$ Taq DNA polymerase and $11.8 \mu \mathrm{L} \mathrm{H}_{2} \mathrm{O}$. PCR was run in a Perkin 


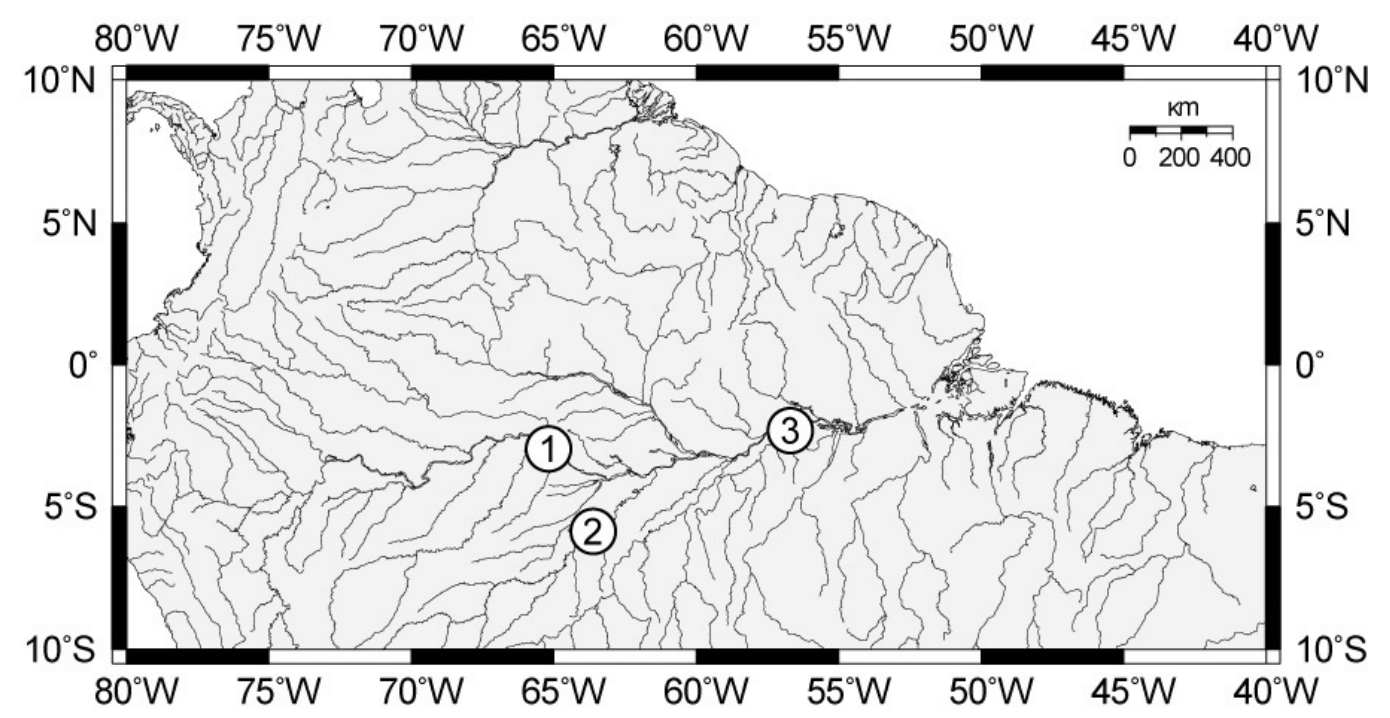

Figure 1. Sample locations. 1. RDS Mamirauá (AM). 2. Abufari (AM). 3. Terra Santa (PA).

Elmer GeneAmp PCR System 9600 and had the following steps: an initial denaturation step at $92^{\circ} \mathrm{C}$ for $1 \mathrm{~min}$, followed by 35 cycles of annealing at $55^{\circ} \mathrm{C}$ for $1 \mathrm{~min}$, and extension at $72^{\circ} \mathrm{C}$ for $1 \mathrm{~min}$. The PCR products were purified according to manufacturer recommendations using the Concert Nucleic Acid Purification System (Life Technologies).

\section{DNA sequencing and statistical analysis}

Sequencing reactions were performed according to manufacturer recommendations using the Terminator Cycle Sequencing kit (GE-Healthcare), and resolved on a MegaBACE 1000 automated sequencer (GE-Healthcare). Partial ND1 nucleotide sequences were edited using the BioEdit Version 5.0.6 program (Hall, 1999) and aligned by eye. The haplotype network was reconstructed using the TCS version 1.13 program (Clement et al., 2000), which implements the algorithm described by Templeton et al. (1992). The DnaSP v5 program (Librado and Rozas, 2009) was used to estimate number of haplotypes, segregating sites (a site that is polymorphic in the data), haplotype diversity (probability that two randomly chosen haplotypes are different in the sample; Nei, 1987) and nucleotide diversity (average number of nucleotide differences per site between any two DNA sequences randomly chosen from the sample population; Nei and Li, 1979). The mutation-drift genetic equilibrium of mtDNA alleles was tested using Tajima's $D$ test (Tajima, 1989), and Fu's $F s$ test $(\mathrm{Fu}, 1997)$, which are based on the infinite-site model under the hypothesis of selective neutrality and population equilibrium. Population subdivision and structure were examined using analysis of molecular variance (AMOVA) (Excoffier et al., 1992), and pair-wise population $\theta_{S T}$ (Cockerham and Weir, 1993) as implemented in the ARLEQUIN v. 3.0 program (Excoffier et al., 2005). 


\section{RESULTS AND DISCUSSION}

The total alignment of the partial ND1 gene consisted of $415 \mathrm{bp}$. The average nucleotide base proportions were $27.69 \%$ cytosine, $32.05 \%$ thymine, $29.40 \%$ adenine, and $10.85 \%$ guanine, providing evidence of a bias against $\mathrm{G}$ and an A-T bias $(61.45 \%)$, typical of vertebrate mitochondrial genes (Zhang and Hewitt, 1996).

In the three populations of $P$. sextuberculata, a total of 7 polymorphic sites were found (Table 1; Figure 2), 6 arising from transitions and 1 from a transversion. The low levels of genetic variability found for the partial sequence of the ND1 gene in P. sextuberculata (Table 2) are consistent with those suggested by Avise et al. (1992) for the low rate of molecular evolution of mtDNA in turtles compared with other taxa. However, such a suggestion may be more frequent for coding genes, since non-coding regions, as observed in ribosomal genes and mitochondrial control region, have been broadly used for analyses of population level (Seddon et al., 1998; Sites Jr. et al., 1999; Pearse et al., 2006a). Protein-coding genes, such as cytochrome $b$, have been characterized as relatively invariable in E. marmorata (Janzen et al., 1997) and P. lewyana (Vargas-Ramírez et al., 2007), although they have shown sufficiently high variation for phylogeographic analyses in other species, such as in North American softshell turtles Apalone spp (Weisrock and Janzen, 2000). Similar high levels of genetic variability were observed for the segments of ND4 in Emys marmorata (Spinks and Shaffer, 2005). Such results suggest that proteincoding genes and non-coding genes may display patterns of different levels of genetic variability in different turtle taxa.

\begin{tabular}{|c|c|c|c|}
\hline Haplotype & Abufari & RDS Mamirauá & Terra Santa \\
\hline 02Abuf - H1 & 24 & 10 & 22 \\
\hline 03Abuf - H2 & 1 & & \\
\hline 11Abuf - H3 & 2 & & 1 \\
\hline 14Abuf - H4 & 1 & & \\
\hline 21Abuf - H5 & 1 & & \\
\hline 43RDSM - H6 & & 1 & \\
\hline \multirow[t]{2}{*}{ 72TSan - H7 } & & & 1 \\
\hline & 29 & 11 & 24 \\
\hline
\end{tabular}

Table 2. Main genetic patterns for Podocnemis sextuberculata.
\begin{tabular}{lcccccc}
\hline Sampling site & N & No. of haplotypes & Gene (haplotype) diversity & Nucleotide diversity (per site) & Tajima's $D$ test & Fu's $F$ s test \\
\hline RDSM & 11 & 2 & $0.182 \pm 0.14$ & 0.00044 & -1.1285 & -0.410 \\
Abufari & 29 & 5 & $0.318 \pm 0.01$ & 0.00096 & -1.5761 & -3.195 \\
Terra Santa & 24 & 3 & $0.157 \pm 0.09$ & 0.00058 & -1.733 & -1.404 \\
All & 64 & 7 & $0.235 \pm 0.07$ & 0.00074 & $-2.003^{*}$ & $-6.570^{*}$ \\
\hline
\end{tabular}

RDSM $=$ Reserva de Desenvolvimento Sustentável Mamirauá. *Significant at the 5\% level. 


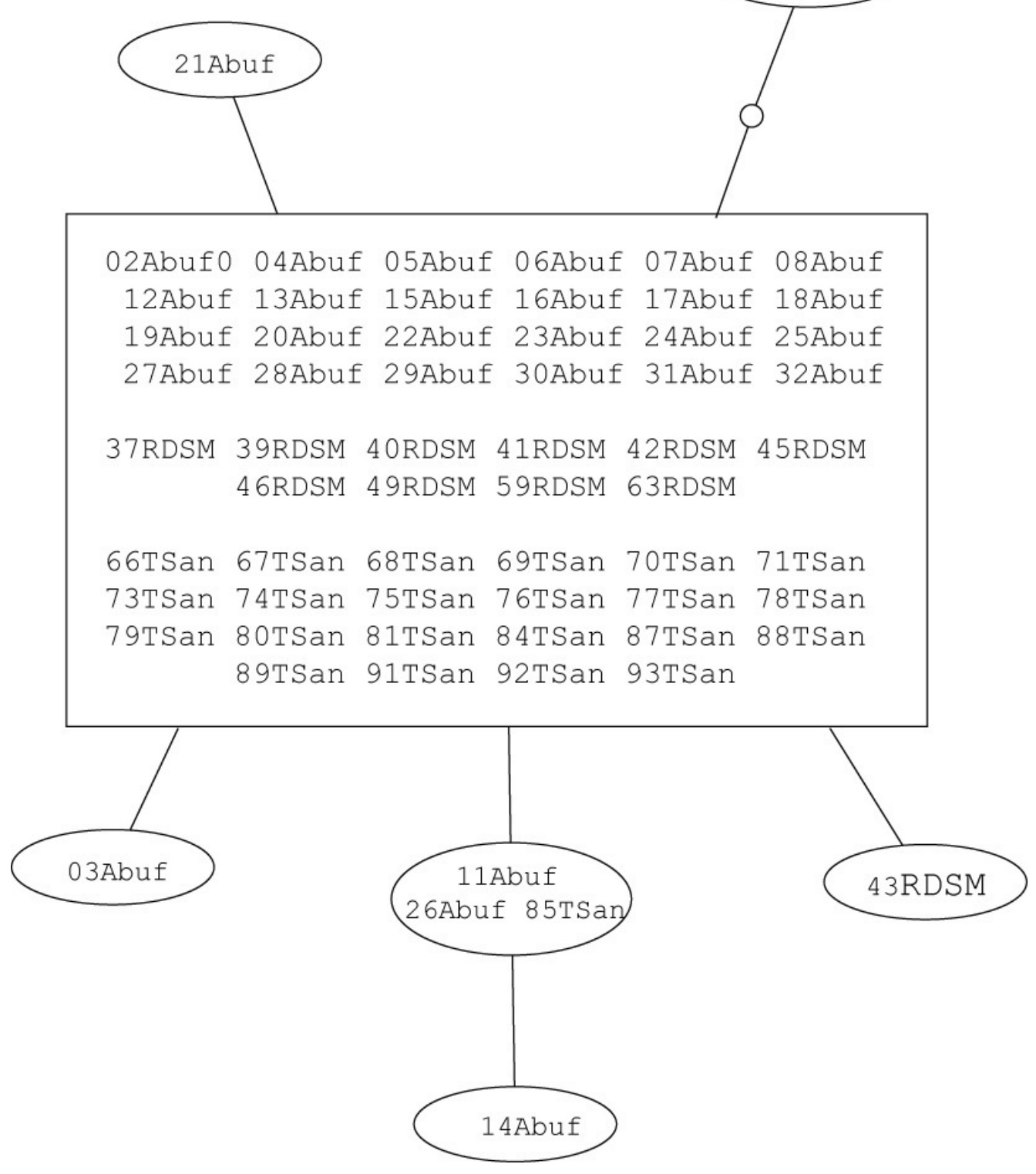

Figure 2. Haplotype network found in the partial ND1 gene sampled in 64 individuals of Podocnemis sextuberculata from Reserva de Desenvolvimento Sustentável Mamirauá (RDSM), Abufari (Abuf), and Terra Santa (TSan).

Considering these aspects of mtDNA genes, it was not our aim to relate the low levels of genetic variability observed with the effects of pressure $P$. sextuberculata has suffered from 
being hunted, as such would require more variable markers. However, the partial fragment of the ND1 gene proved to be a good marker to demonstrate the lack of population structure.

\section{Lack of population structure}

The partial ND1 sequence was shown to be a good molecular marker to provide us with a tool for detecting genetic differentiation within this species. There were seven haplotypes found in the three populations sampled (Table 1, Figure 2), the most common haplotype being 02Abuf, shared by individuals from the three populations, and present in $87.5 \%$ of the individuals sampled. This haplotype was shared among individuals from all the locations sampled, where it was found in $82.75 \%$ of the individuals from Abufari, $90.9 \%$ of those from RDS Mamirauá, and $91.66 \%$ of those from Terra Santa. Singletons and rare haplotypes were also observed. The distribution of the haplotypes did not indicate any correlation with the geographic location of the individuals sampled, suggesting the lack of geographic structure.

The high level of haplotype sharing observed among the three areas was also confirmed by the observed high gene flow, where the smallest number of migrants per generation was $N m=35.37$ (Table 3), with the greatest gene flow found between Abufari and Terra Santa. According to Kimura and Maruyama (1971), when Nm assumes values greater than four between localities, the localities can be considered belonging to as a single panmictic population, whereas $\mathrm{Nm}$ less than one indicates that the localities are differentiated. The high $\mathrm{Nm}$ observed among the localities sampled would indicate that $P$. sextuberculata has a high migration or dispersion rate, and confirms what the ecological data had already suggested, that this species has a high capacity for dispersion (Fachín-Terán et al., 2006).

Table 3. Gene flow between the three sampling locations of Podocnemis sextuberculata.

\begin{tabular}{lccc}
\hline Location & Abufari & RDSM & Terra Santa \\
\hline Abufari & - & - & - \\
RDSM & $\infty$ & - & - \\
Terra Santa & 35.37 & 68.27 & - \\
\hline
\end{tabular}

RDSM = Reserva de Desenvolvimento Sustentável Mamirauá.

According to Gibbons (1986), many chelonian species move great distances in response to seasonal changes, but the response to adverse conditions can vary within or among species. In the RDS Mamirauá, $P$. sextuberculata moves in response to water level, the opposite of $P$. unifilis, where some individuals remain in the reserve. Fachín-Terán et al. (2006), observing $P$. sextuberculata in the RDS Mamirauá, demonstrated by means of radio-telemetry the migration from the feeding places to breeding areas on the Japurá and Solimões Rivers. One individual of $P$. sextuberculata marked in RDS Mamirauá was also found in the Middle Juruá River, about $300 \mathrm{~km}$ away from the RDS Mamirauá (Andrade $\mathrm{P}$, personal communication).

The AMOVA results $\left(\theta_{S T}=0.00876, \mathrm{P}>0.05\right)$ suggest that there is no genetic differentiation among the groups of individuals from the three areas sampled (Table 4$)$. In interpreting the $\theta_{S T}$ numbers (Table 3 ) according to Wright (1931), a value less than 0.05 can be 
Table 4. Results of analysis of molecular variance (AMOVA).

\begin{tabular}{lcc}
\hline Source of variation & Variance components & Percentage of variation \\
\hline Among population & 0.00311 & 0.88 \\
Within population & 0.35195 & 99.12 \\
Total & 0.35506 & \\
\hline
\end{tabular}

$\theta_{S T}=0.00876(\mathrm{P}=0.24536 \pm 0.01442)$.

considered an indicator of low genetic differentiation. The lack of genetic structure between great geographic distances and extensive gene flow between the localities studied corroborate observations in field work. Fachín-Terán et al. (2006), utilizing the mark-recapture method, observed that the distances covered by individuals of $P$. sextuberculata varied greatly, and evidence of territoriality that was not found in the RDS Mamirauá. The authors suggest that the population of $P$. sextuberculata is open, as there is a very low recapture rate $(3.6 \%)$, indicating the dispersion of a high number of marked individuals. Such results indicate that $P$. sextuberculata individuals make seasonal migrations. At the beginning of the dry period, to avoid unfavorable conditions, they leave the flooded forests and lakes and head towards the main river channels (Fachín-Terán et al., 2006).

Despite the lack of population genetic structure observed over the large distances between the three collection locations (the largest distance being approximately $1300 \mathrm{~km}$ between the Terra Santa and RDS Mamirauá locations), individuals from other areas of the Amazon Basin need to be investigated to confirm panmixia among all the tributaries of the Amazon Basin, where the species occurs. It may also be necessary to study other genetic markers to elucidate possible population differences to help with any management plan.

\section{ACKNOWLEDGMENTS}

Research supported by grants to L.A.S. Manjeló from CNPq/PTU (\#46.9940/2000-0) and through the Termo de Cooperação Técnica Institucional between IBAMA and UFAM (Proc. $\# 02005.002214 / 97-11, \# 02005.000049 / 98-16$, and \#02005.003404/01-40). Permission to collect tissue samples was granted by RAN/IBAMA (\#02005.000689/98-16, \#02005.001579/9764, \#113/2006). The authors thank the "Pé-de-pincha" chelonian sustainable management community program (IBAMA \#02005.000352/99-45, and \#02010.002988/99-99) for field support. This study is part of T.S. Silva's dissertation in the Genetics and Evolution collaborative program of Universidade Federal de São Carlos/Universidade Federal do Amazonas. T.J. Silva was a PhD student at the Biotechnology program of Universidade Federal do Amazonas supported by a fellowship from CAPES.

\section{REFERENCES}

Avise JC, Bowen BW, Lamb T, Meylan AB, et al. (1992). Mitochondrial DNA evolution at a turtle's pace: evidence for low genetic variability and reduced microevolutionary rate in the Testudines. Mol. Biol. Evol. 9: 457-473.

Clement M, Posada D and Crandall KA (2000). TCS: a computer program to estimate gene genealogies. Mol. Ecol. 9: $1657-1659$.

Cockerham CC and Weir BS (1993). Estimation of gene flow from $F$-statistics. Evolution 47: 855-863.

Excoffier L, Smouse PE and Quattro JM (1992). Analysis of molecular variance inferred from metric distances among 
DNA haplotypes: application to human mitochondrial DNA restriction data. Genetics 131: 479-491.

Excoffier L, Laval G and Schneider S (2005). Arlequin (version 3.0): an integrated software package for population genetics data analysis. Evol. Bioinform. Online 1: 47-50.

Fachín-Terán A, Vogt RC and Thorbjarnarson JB (2000). Padrões de Caça e Uso de Quelônios na Reserva de Desenvolvimento Sustentável Mamirauá, Amazonas, Brasil. In: Manejo de Fauna Silvestre en Amazonia y Latinoamérica (Cabrera E, Mercolli C and Resquin R, eds.). Guarani Raity, Asunción, 323-338.

Fachín-Terán A, Vogt RC and Thorbjarnarson JB (2003). Estrutura populacional, razão sexual e abundancia de Podocnemis sextuberculata (Testudines, Podocnemididae) na reserva de desenvolvimento sustentável Mamirauá, Amazonas, Brasil. Phyllomedusa 2: 43-63.

Fachín-Terán A, Vogt RC and Thorbjarnarson JB (2006). Seasonal movements of Podocnemis sextuberculata (Testudines: Podocnemididae) in the Mamirauá sustainable development reserve, Amazonas, Brazil. Chelon. Conservat. Biol. 5: 18-24.

Fantin C, Viana LS, Monjeló LAS and Farias IP (2008). Polyandry in Podocnemis unifilis (Pleurodira; Podocnemididae), the vulnerable yellow-spotted Amazon River turtle. Amphibia-Reptilia 29: 479-486.

Finch CE (1990). Longevity, Senescence, and the Genome. University of Chicago Press, Chicago.

Frankham R, Ballou JR and Briscoe DA (2002). Introduction to Conservation Genetics. Cambridge University Press, Cambridge.

Fu YX (1997). Statistical tests of neutrality of mutations against population growth, hitchhiking and background selection. Genetics 147: 915-925.

Gibbons JW (1986). Movement patterns among turtle populations: Applicability to management of the desert tortoise. Herpetologica 42: 104-113.

Hall T (1999). BioEdit: a user-friendly biological sequence alignment editor and analysis program for Windows 95/98/ NT. Nucleic Acids Symp. Ser. 41: 95-98.

Hrbek T, Kucuk F, Frickey T, Stolting KN, et al. (2002). Molecular phylogeny and historical biogeography of the Aphanius (Pisces, Cyprinodontiformes) species complex of central Anatolia, Turkey. Mol. Phylogenet. Evol. 25: 125-137.

IBAMA (1989). Projeto Quelônios da Amazônia - 10 Anos. Brasília.

IUCN (2009). The IUCN Red List of Threatened Species. Available at [http://www.redlist.org.]. Accessed May 12, 2009.

Janzen FJ, Hoover SL and Shaffer HB (1997). Molecular phylogeography of the western pond turtle (Clemmys marmorata): Preliminary results. Chelonian Conserv. Biol. 2: 623-626.

Kimura M and Maruyama T (1971). Pattern of neutral polymorphism in a geographically structured population. Genet. Res. 18: 125-131.

Librado P and Rozas J (2009). DnaSP v5: a software for comprehensive analysis of DNA polymorphism data. Bioinformatics 25: 1451-1452.

Lutz PL, Prentice HM and Milton SL (2003). Is turtle longevity linked to enhanced mechanisms for surviving brain anoxia and reoxygenation? Exp. Gerontol. 38: 797-800.

Nei M (1987). Molecular Evolutionary Genetics. Columbia University Press, New York.

Nei M and Li WH (1979). Mathematical model for studying genetic variation in terms of restriction endonucleases. Proc. Natl. Acad. Sci. U. S. A. 76: 5269-5273.

Pearse DE, Arndt AD, Valenzuela N, Miller BA, et al. (2006a). Estimating population structure under nonequilibrium conditions in a conservation context: continent-wide population genetics of the giant Amazon river turtle, Podocnemis expansa (Chelonia; Podocnemididae). Mol. Ecol. 15: 985-1006.

Pearse DE, Dastrup RB, Hernandez O and Sites Jr JW (2006b). Paternity in an Orinoco population of endangered Arrau River turtles, Podocnemis expansa (Pleurodira; Podocnemididae), from Venezuela. Chelon Conserv. Biol. 5: 232238.

Sambrook J, Fritsch EF and Maniatis T (1989). Molecular Cloning. A Laboratory Manual. 2nd edn. Cold Spring Harbor Laboratory Press, New York.

SEBRAE (1995). Criação de Quelônios em Cativeiro. Programa de Informação. SEBRAE, Manaus.

Seddon JM, Baverstock PR and Georges A (1998). The rate of mitochondrial 12S rRNA gene evolution is similar in freshwater turtles and marsupials. J. Mol. Evol. 46: 460-464.

Sites Jr JW, Fitzsimmons NN, Silva NJ and Cantarelli VH (1999). Conservation genetics of the giant Amazon River turtle (Podocnemis expansa; Pelomedusidae) - inferences from two classes of molecular markers. Chelon. Conservat. Biol. 3: 454-463.

Spinks PQ and Shaffer HB (2005). Range-wide molecular analysis of the Western Pond Turtle (Emys marmorata): cryptic variation, isolation by distance, and their conservation implications. Mol. Ecol. 14: 2047-2064.

Tajima F (1989). Statistical method for testing the neutral mutation hypothesis by DNA polymorphism. Genetics 123: 585-595. 
Templeton AR, Crandall KA and Sing CF (1992). A cladistic analysis of phenotypic associations with haplotypes inferred from restriction endonuclease mapping and DNA sequence data. III. Cladogram estimation. Genetics 132: 619-633.

Vargas-Ramírez M, Chiari Y, Castaño-Mora OV and Menken SBJ (2007). Low genetic variability in the endangered Colombian endemic freshwater turtle Podocnemis lewyana (Testudines, Podocnemididae). Contrib. Zool. 76: 1-7.

Weisrock DW and Janzen FJ (2000). Comparative molecular phylogeography of North American softshell turtles (Apalone): Implications for regional and wide-scale historical evolutionary forces. Mol. Phylogenet. Evol. 14: 152164.

Wright S (1931). Evolution in Mendelian populations. Genetics 16: 97-159.

Zhang DX and Hewitt GM (1996). Nuclear integrations: challenges for mitochondrial DNA markers. Trends Ecol. Evol. 11: $247-251$ 